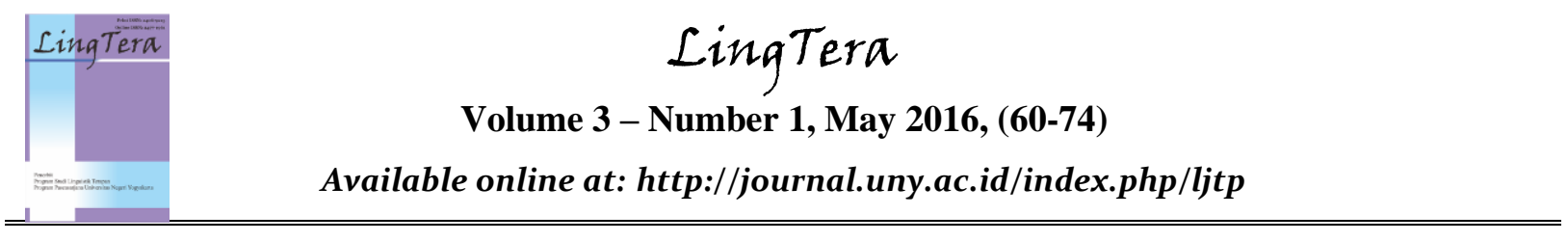

\title{
PENGARUH MOTIVASI, KEYAKINAN DIRI, DAN PERSEPSI SISWA TERHADAP APRESIASI KARYA SASTRA SISWA SMP
}

\author{
Mimi Alpian $^{1 *}$, Maman Suryaman ${ }^{2}$ \\ ${ }^{1}$ Prodi Pendidikan Bahasa dan Sastra Indonesia, STKIP Hamzanwadi Selong. Jalan TGKH M. \\ Zainudin Abdul Majid No. 132 Pancor, Selong, Lombok Timur, 83611, Indonesia. \\ 2 Jurusan Pendidikan Bahasa dan Sastra Indonesia, Universitas Negeri Yogyakarta. Jalan Colombo No. \\ 1, Karangmalang, Yogyakarta 55281, Indonesia. \\ * Korespondensi Penulis. Email: mimialpian@ gmail.com, Telp: +6281803632709
}

\begin{abstract}
Abstrak
Tujuan penelitian ini adalah untuk mengetahui pengaruh: (1) motivasi; (2) keyakinan diri; (3) persepsi siswa terhadap apresiasi karya sastra siswa. Penelitian ini menggunakan pendekatan kuantitatif. Jenis penelitian yang digunakan adalah penelitian survey yang mengandung tiga variabel bebas dan satu variabel terikat. Populasi penelitian ini adalah seluruh siswa SMP di Kabupaten Lombok Timur. Sampel sejumlah 383 siswa ditentukan menggunakan teknik proportional stratified sampling. Data dikumpulkan dengan menggunakan angket motivasi, keyakinan diri, persepsi siswa, dan apresiasi karya sastra. Analisis data menggunakan statistik deskriptif dan analisis regresi ganda. Hasil penelitian ini ada empat. Pertama, motivasi berpengaruh terhadap apresiasi karya sastra. Kedua, keyakinan diri berpengaruh terhadap apresiasi karya sastra. Ketiga, persepsi siswa berpengaruh terhadap apresiasi karya sastra, dan Keempat, motivasi, keyakinan diri, dan persepsi siswa berpengaruh secara bersama-sama terhadap apresiasi karya sastra.
\end{abstract}

Kata Kunci: motivasi, keyakinan diri, persepsi, dan apresiasi karya sastra

\section{THE EFFECT OF MOTIVATION, SELF-EFFICACY, AND PERCEPTION ON THE LITERATURE APPRECIATION OF THE STUDENTS OF JUNIOR HIGH SCHOOLS}

\begin{abstract}
This study aims to determine the effect of: (1) students' motivation; (2) students' self-efficacy; (3) students' perception on the literature appreciation of the students of junior high schools in Kabupaten Lombok Timur. This study used the quantitative approach. This research was a survey containing three independent variables and one dependent variable. The population was all students of junior high schools in Kabupaten Lombok Timur. A sample of 383 students was established using proportional stratified sampling technique. The data were collected using the motivation questionnaire, self-efficacy questionnaire, students' perception questionnaire, and students' literature appreciation questionnaire. To determine the effect, the researchers used descriptive statistics and multiple regression analysis. The results of this study are as follows. First, motivation affects students' literature appreciation. Second, the self-efficacy affects students' literature appreciation. Third, the perception affects students' literature appreciation. Fourth, motivation, self-efficacy, and perceptions simultaneously affect students' literature appreciation.
\end{abstract}

Keywords: motivation, self-efficacy, perception, students literature appreciation

How to Cite: Alpian, M., \& Suryaman, M. (2016). Pengaruh motivasi, keyakinan diri, dan persepsi siswa terhadap apresiasi karya sastra siswa SMP. LingTera, 3(1), 60-74. doi:http://dx.doi.org/10.21831/lt.v3i1.8663

Permalink/DOI: http://dx.doi.org/10.21831/lt.v3i1.8663 


\section{LingTera, 3 (1), May 2016 - 61 \\ Mimi Alpian, Maman Suryaman}

\section{PENDAHULUAN}

Bahasa Indonesia merupakan bahasa negara yang memiliki kedudukan dan peran yang sangat penting dalam menjaga persatuan dan kesatuan bangsa. Pentingnya peran dan kedudukan bahasa Indonesia tercantum secara jelas di dalam ikrar Sumpah Pemuda yang berbunyi: "Kami putra dan putri Indonesia menjunjung bahasa persatuan, bahasa Indonesia" (Alwi, Lapoliwa, \& Darmowidjojo, 2003, p.1). Oleh karena itu, pengembangan bahasa Indonesia terus digalakkan melalui berbagai cara sehingga tetap terjaga kelestariannya. Menteri pendidikan dan kebudayaan Indonesia, Muhammad Nuh, menyampaikan pendapatnya tentang usaha untuk menjaga dan memperkuat bahasa Indonesia yang antara lain dapat dilakukan dengan memupuk kecintaan terhadap bahasa Indonesia, memperkuat guru bahasa Indonesia, dan memperbanyak ruang-ruang ekspresi, seperti menampilkan puisi, drama, dan teater (Kompas, Edisi 28 Oktober 2013).

Mata pelajaran bahasa Indonesia secara formal mencantumkan berbagai materi yang tidak hanya berhubungan dengan kompetensi berbahasa yang terfokus pada penggunaan bahasa secara praktis, sesuai dengan kaidah bahasa baku, melainkan juga berhubungan dengan kompetensi bersastra yang merupakan bagian penting dalam upaya pelestarian dan pemertahanan bahasa Indonesia. Dengan adanya kegiatan apresiasi karya sastra dalam materi pembelajaran bahasa Indonesia diharapkan siswa lebih mampu mengembangan kompetensi dan kemampuan yang dimiliki. Moody (Sujarwanto \& Jabrohim, Ed., 2002, p.528) menjelaskan bahwa "melalui pembelajaran apresiasi sastra siswa diharapkan memperoleh berbagai macam keuntungan, baik yang menyangkut pengetahuan maupun yang menyangkut keterampilan (berbahasa), dan berbagai kapasitas psikologis yang dibutuhkan oleh manusia atau individu yang sedang berkembang."

Untuk mengetahui perkembangan kompetensi dan tingkat pengetahuan siswa dalam pembelajaran bahasa Indonesia khususnya yang berhubungan dengan sastra dapat dilakukan dengan memahami sikap dan penguasaan empat keterampilan dasar yang diberikan selama proses pembelajaran. Empat keterampilan tersebut tentunya berhubungan dengan kegiatan yang bersifat reseptif maupun produktif. Adapun keterampilan-keterampilan yang dimaksud menurut Razak (Anshori \& Sumiyadi, 2009, p.301) yaitu kemampuan mendengar dan membaca sebagai kompetensi yang bersifat reseptif dan kemampuan berbicara dan menulis sebagai kompetensi yang bersifat produktif. Keempat keterampilan tersebut tercantum secara implisit dalam standar kompetensi mata pelajaran bahasa Indonesia.

Kedudukan sastra sebagai salah satu materi pembelajaran bahasa Indonesia tidak hanya bertujuan untuk meningkatkan pengetahuan atau kemampuan berbahasa siswa melainkan juga untuk meningkatkan kemampuan berapresiasinya. Rusyana (Effendi, 2008, p.xii) memberikan penjelasan yang penting terkait dengan pengajaran sastra, yakni: "muara dari pengajaran sastra adalah agar siswa memperoleh pengetahuan tentang sastra (literary knowlwdge) dan pengalaman bersastra (literary experience). Selain itu, pengetahuan tentang sastra diperoleh melalui pemahaman pengetahuan teoretis dan historis, sedangkan pengalaman bersastra diperoleh melalui kegiatan (pengalaman) berapresiasi dan berekspresi sastra."

Fakta yang ditemukan di lapangan menunjukkan jika kegiatan apresiasi sastra kadangkala tidak didukung oleh pelaksana, penyelenggara dan kondisi lingkungan yang dibutuhkan. Terbukti dari persepsi umum siswa yang sering menganggap kegiatan apresiasi sastra sebagai sebatas usaha atau tujuan yang dilakukan untuk mendapatkan nilai semata, bukan sebagai sebuah kebutuhan yang dilakukan secara tersadar.

Apresiasi sastra secara umum memiliki hubungan dengan psikologis orang yang terlibat dalam proses pemaknaannya. Kondisi itu tidak terlepas dari pengertian apresiasi sastra itu sendiri yang sering diartikan sebagai sebuah kegiatan untuk menikmati, menghayati dan mengambil berbagai informasi yang disampaikan penulis sebagai wujud penghargaan terhadap karya sastra. Hayati \& Muslih (2012, p.5) berpendapat bahwa "apresiasi sastra merupakan penghargaan, penilaian, dan pengertian terhadap karya sastra, baik yang berbentuk puisi maupun prosa". Kegiatan psikologis yang berkaitan apresiasi sastra yang dimaksud pada hakikatnya didasari oleh kegiatan awal yang harus dilakukan dalam apresiasi karya sastra yakni kegiatan membaca.

Pengujian kemampuan dan kompetensi siswa dari sebuah proses pembelajaran yang dilaksanakan seringkali menjadi acuan dalam penentuan keberhasilan proses pembelajaran. Tahap pengukuran kemampuan siswa secara umum didasarkan pada analisis yang dilakukan 


\section{Ling Tera, 3 (1), May 2016 - 62 \\ Mimi Alpian, Maman Suryaman}

berdasarkan teori taksonomi Bloom yang melibatkan unsur-unsur kognitif, afektif, dan psikomotor (Uno \& Koni, 2012, p.61). Kemampuan kognitif siswa akan diukur berdasarkan tes kemampuan yang disesuaikan dengan materi apresiasi sastra yang diberikan, begitu pula dengan aspek afektif yang melibatkan perhatian pada aspek sikap siswa dalam mengapresiasi sastra. Bagian terakhir yang diukur adalah bagaimana kecepatan dan gerak motorik siswa dalam melakukan apresiasi sastra. Unsur-unsur tersebutlah yang menjadi landasan pengukuran dan penilaian keberhasilan siswa dalam pelaksanaan kegiatan apresiasi karya sastra.

Beberapa sumber yang ada menunjukkan bahwa peringkat membaca siswa di Indonesia masih rendah karena menduduki posisi ke-57 dari 65 negara di dunia, sesuai dengan data yang diperoleh dari PISA (Program for International Student Assessment Tahun 2009). Data terbaru yang dikeluarkan oleh PISA pada tahun 2013 menunjukkan jika Indonesia berada pada urutan ke-64 dari 65 negara di dunia, satu tingkat lebih baik dibanding dengan negara Peru yang menduduki urutan terendah (Kompas, Edisi 5 Desember 2013). Selain itu, PIRLS (Progress in International Reading Literacy Study), sebuah studi internasional tentang literasi membaca untuk siswa sekolah dasar yang dikoordinasi oleh IEA (The International association for the Evaluation of Educational Achievement) menghasilkan data jika peringkat membaca literasi siswa di Indonesia menduduki peringkat ke-41 dari 45 negara. Hasil penilaian tersebut digunakan sebagai salah satu landasan untuk melihat keberhasilan kegiatan apresiasi karya sastra siswa karena membaca merupakan salah satu keterampilan utama dalam penilaian apresiasi sastra.

Rendahnya kemampuan apresiasi sastra siswa di Kabupaten Lombok Timur ditunjukkan juga oleh nilai ujian nasional bahasa Indonesia yang terkait dengan apresiasi sastra. Hal itu didukung oleh data yang diperoleh dari Badan Standar Nasional Pendidikan (BSNP) tentang hasil ujian nasional mata pelajaran Bahasa Indonesia selama empat tahun terakhir. Berikut ini rincian data hasil ujian nasional siswa SMP di Kabupaten Lombok Timur.
Tabel 1. Nilai Ujian Nasional SMP di Lombok Timur Empat Tahun Terakhir

\begin{tabular}{ccccc}
\hline $\begin{array}{c}\text { Tahun } \\
\text { Ajaran }\end{array}$ & $\begin{array}{c}\text { Bahasa } \\
\text { Indonesia }\end{array}$ & $\begin{array}{c}\text { Bahasa } \\
\text { Inggris }\end{array}$ & IPA & MTK \\
\hline $2008 / 2009$ & 6,78 & 7,08 & 7,21 & 8,06 \\
$2009 / 2010$ & 7,17 & 7,48 & 7,75 & 7,69 \\
$2010 / 2011$ & 7,60 & 7,84 & 7,69 & 7,82 \\
$2011 / 2012$ & 8,17 & 7,81 & 8,24 & 8,19 \\
\hline
\end{tabular}

Sumber: Puspendik Balitbang Kemendiknas

Data yang ada memperlihatkan jika nilai ujian bahasa Indonesia siswa di Kabupaten Lombok Timur masih di bawah nilai ujian nasional pelajaran IPA dan Matematika sedangkan dengan pelajaran bahasa Inggris, nilai bahasa Indonesia lebih tinggi hanya pada tahun 2011/ 2012. Tingkat daya serap siswa sesuai data yang didapatkan 'khususnya pada indikator "menentukan sudut pandang pengarang dalam penggalan cerpen" menempati urutan terendah, yaitu 26,43 (skala 100) atau 2,64 (skala 10), begitu juga dengan rata-rata pembelajaran apresiasi sastra (cerpen, puisi, drama, novel dan pantun) untuk dua tahun terakhir rata-rata 62,88 (6,29 skala 10$)$ dan 74,64 (7,46 skala 10) masih di bawah nilai rata-rata ujian nasional Bahasa Indonesia. Data tersebut secara langsung menunjukkan jika kegiatan siswa dalam mengapresiasi sastra perlu diteliti. Salah satu alternatifnya yakni dengan mengidentifikasi faktor-faktor yang mempengaruhi kegiatan apresiasi karya sastra siswa SMP tersebut.

Beberapa faktor yang mempengaruhi prestasi belajar menurut Syah (2010, p.129) adalah faktor internal dan faktor eksternal. Berdasarkan pendapat tersebut dapat dilihat jika faktor internal dan ekstrenal memiliki peran penting dalam menentukan kemampuan siswa pada berbagai tingkat kemampuan dan kompetensi yang dimiliki. Berbagai faktor yang berasal dari dalam diri siswa bisa berupa dorongan atau motivasi untuk melakukan kegiatan tertentu, keyakinan untuk terus berjuang dalam berbagai situasi dan kondisi serta berbagai faktor yang mengarahkan siswa untuk mempersepsi berbagai karya sastra maupun pengetahuan lainnya.

Pendapat di atas tidak hanya didukung oleh seorang ahli, melainkan juga beberapa ahli lainnya yang menyampaikan jika motivasi adalah aspek penting dari pengajaran dan pembelajaran. Dengan kata lain, siswa yang tidak mempunyai motivasi tidak akan berusaha keras untuk belajar. Hal tersebut sesuai dengan pendapat Santrock (2011, p.509) yang menyatakan jika "siswa yang bermotivasi tinggi senang ke 


\section{LingTera, 3 (1), May 2016 - 63 \\ Mimi Alpian, Maman Suryaman}

sekolah dan menyerap proses belajar". Selain itu, Pulungan (2008, p.48) menyampaiakn bahwa "faktor, yang sangat menentukan prestasi belajar siswa adalah motivasi siswa itu sendiri untuk berprestasi". Penelitian yang dilakukan oleh Pertiwi (2012) juga menunjukkan bahwa motivasi siswa berpengaruh secara positif terhadap kemampuan meresepsi cerpen siswa SMP kelas IX se-Kabupaten Banyumas dengan hasil $25,6 \%$ sedangkan $74,4 \%$ dipengaruhi oleh faktor lain seperti persepsi siswa, kebiasaan membaca, dan penguasaan kosakata.

Untuk melakukan kegiatan apresiasi sastra maka dibutuhkan keyakinan diri yang kuat dari siswa. Keyakinan diri didefinisikan oleh Santrock (2011, p.523) sebagai "keyakinan bahwa dirinya bisa menguasai situasi dan memproduksi hasil positif". Berdasarkan pengertian tersebut, dapat disimpulkan bahwa keyakinan diri sangat dibutuhkan oleh siswa untuk mengembangkan diri secara maksimal sehingga lebih mantap dan epektif ketika melakukan kegiatan-kegiatan yang berhubungan apresiasi sastra. Pendapat ini sesuai dengan hasil penelitian yang dilakukan oleh Ibrahim (2011) yang mengatakan jika keyakinan diri secara signifikan mempengaruhi hasil belajar siswa dalam membaca. Sesuai dengan konteks awal yang telah dijelaskan bahwa membaca menjadi sebuah kegiatan dasar yang dilakukan oleh siswa di dalam melakukan apresiasi sastra, tanpa membaca maka siswa tidak akan bisa mengetahui dan menikmati karya sastra terlebih untuk mengapresiasinya.

Keyakinan diri siswa dibutuhkan dalam pembelajaran apresiasi sastra karena di dalam prosesnya siswa akan menemukan berbagai jenis karya yang memiliki tingkat kesulitan makna dan unsur yang membangunnya. Pentingnya keyakinan diri dalam mengapresiasi sastra sesuai dengan pendapat Ashton \& Webb (Santrock, 2011, p.524) yang menyatakan bahwa "keyakinan diri berhubungan dengan prestasi akademik siswa untuk pelajaran matematika dan bahasa". Untuk itu, motivasi dan keyakinan diri menjadi dua aspek penting yang perlu diperhatikan secara seksama karena pada dasarnya hal ini memiliki ruang lingkup tersendiri.

Untuk bisa melaksanakan proses apresiasi sastra secara maksimal, siswa harus melalui tahap awal berupa tahap persepsi terhadap karya sastra itu sendiri. Persepsi yang dimaksud di dalam hal ini adalah "bagaimana siswa mengamati dan memahami tanda-tanda hitam yang terkandung di dalam sebuah teks sastra dengan seksama". Hal itu sesuai dengan pendapat Aminuddin (2011,p.16) yang menyatakan bahwa "kekompleksan dalam kegiatan apresiasi sastra melibatkan berbagai aspek, baik fisik, mental, bekal pengalaman, pengetahuan maupun aktivitas berpikir dan merasa". Secara keseluruhan, hal itu terproses melalui tahapan (1) persepsi, (2) rekognisi, (3) komprehensi, (4) interpretasi, (5) evaluasi, (6) kreasi atau utilisasi. Selain itu, masuknya tahap persepsi di dalam kegiatan apresiasi karya sastra dibuktikan oleh penelitian yang dilakukan oleh Carroli (2002) yang menunjukkan bahwasanya terdapat pengaruh persepsi siswa dan guru terhadap praktik pembelajaran apresiasi sastra.

Tahap persepsi siswa dalam kegiatan apresiasi karya sastra harus didukung oleh pengetahuan dan pemahaman siswa tentang sastra itu sendiri. Pengetahuan sastra khususnya yang terkait dengan teori-teori dan sejarah sastra seperti apa yang disampaikan sebelumnya akan membantu siswa untuk memahami setiap unsur pembentuk sastra dan makna atau amanat yang terkandung di dalamnya, sesuai dengan perkembangan zaman. Informasi-informasi yang diperoleh dari data empiris berupa dokumentasi BSNP menunjukkan jika siswa SMP yang ada di Kabupaten Lombok Timur masih memiliki beberapa kekurangan dalam proses pembelajaran bahasa Indonesia, khususnya yang berhubungan dengan kegiatan apresiasi karya sastra.

Dari uraian tersebut rumusan masalah dalam penelitian terbagi menjadi empat yakni: (1). Apakah terdapat pengaruh motivasi terhadap apresiasi karya sastra siswa SMP di Kabupaten Lombok Timur?; (2). Apakah terdapat pengaruh keyakinan diri terhadap apresiasi karya sastra siswa SMP di Kabupaten Lombok Timur?; (3). Apakah terdapat pengaruh persepsi siswa terhadap apresiasi karya sastra siswa SMP di Kabupaten Lombok Timur; dan, (4) Apakah terdapat pengaruh motivasi, keyakinan diri dan persepsi siswa terhadap apresiasi karya sastra siswa SMP di Kabupaten Lombok Timur?. Tujuan dari penelitian ini adalah untuk menjawab rumusan masalah tersebut.

\section{Apresiasi Karya Sastra}

Sastra merupakan salah satu hasil cipta manusia yang dihasilkan melalui perenungan dan pemantapan makna dari bahasa yang digunakan untuk menyampaikannya. Pada awalnya, "istilah apresiasi berasal dari bahasa Inggris appreciation yang berarti penghargaan, penilaian dan pengertian" (Hayati \& Muslich, 2012, 


\section{LingTera, 3 (1), May 2016 - 64 \\ Mimi Alpian, Maman Suryaman}

p.5). Bentuk kata itu berasal dari kata kerja to appreciate yang berarti menghargai, menilai, dan mengerti. Apabila istilah kata kerja tersebut diterjemahkan ke dalam bahasa Indonesia maka akan berubah menjadi mengapresiasi.

Apresiasi sastra pada dasarnya harus dipahami sebagai sebuah kegiatan yang merupakan bagian dari kesenian. Sebagai sebuah seni, apresiasi sastra lebih bersifat subjektif walaupun tetap berdasar pada teori-teori dan sejarah sastra. Saryono (2009, p.28) menjelaskan bahwa "sebagai sebuah kesenian kegiatan apresiasi sastra lebih banyak bersangkutan dengan jiwa, nurani, budi, emosi, rasa dan afeksi daripada keterampilan tangan dan keterampilan fisikal serta bergantung pada waktu, suasana, dan konteks peristiwa". Oleh karena itu, bisa dikatakan jika apresiasi sastra lebih bersifat individual dan sangat dipengaruhi oleh pemahaman dan mental yang bersifat individual dan dianut oleh pelaku apresiasi itu sendiri.

Jamaluddin (2003, p. 40) menjelaskan bahwa "pembelajaran sastra di sekolah harus diarahkan untuk mengubah sikap siswa terhadap sastra sehingga lebih gemar melakukan apresiasi dan bukan berorientasi pada pengetahuan atau teori kesusastraan saja". Bentuk kegiatan apresiasi bisa dilakukan melalui kegiatan langsung dan tidak langsung. Kegiatan langsung dilakukan dengan membaca atau menikmati karya-karya sastra kreatif secara langsung dengan segala bentuk dan ragamnya. Selanjutnya, kegiatan apresiasi yang tidak langsung dilakukan untuk menunjang penikmatan dan pemahaman terhadap suatu karya sastra kreatif misalnya dengan membaca kritik sastra, menonton pagelaran teater, melaksanakan kegiatan baca puisi, mengikuti dan mengadakan lomba cipta karya sastra kreatif dan lain sejenisnya.

Darmono (1979, p.1) menyatakan bahwa "sastra menampilkan gambaran kahidupan dan kehidupan itu sendiri sebagai suatu kenyataan sosial". Pemaparan ini mengisyaratkan jika kegiatan bersastra yang dilakukan tidak hanya mengantarkan siswa dalam memahami unsurunsur sastra yang membantu perkembangan kognitif atau pengetahuan belaka saja, melainkan juga membantu siswa memahami konsep-konsep kehidupan sosial yang ditemukan dalam kehidupan sehari-hari.

Untuk mencapai tujuan apresiasi sastra maka perlu dilakukan penanaman kebiasaan psikologis yang positif di dalam diri siswa. Hal tersebut dapat dilakukan oleh guru dengan melaksanakan proses pembelajaran secara efektif. Kegiatan apresiasi yang dilakukan oleh siswa atau pembaca secara umum dijelaskan oleh Wardani (Sujarwanto \& Jabrohim, Ed., 2002, p.530) sebagai sebuah kegiatan yang terdiri dari beberapa tingkat, yaitu: (1) tingkat menggemari, ditandai oleh adanya rasa tertarik pada buku-buku serta keinginan untuk membacanya; (2) tingkat menikmati, yaitu mulai dapat menikmati cipta sastra karena mulai tumbuhnya pengertian; (3) tingkat mereaksi, yaitu mulai dari keinginan untuk menyatakan pendapat tentang cipta sastra yang dinikmati; (4) tingkat produktif, yaitu mulai ikut menghasilkan cipta sastra; (5) Keempat tingkatan yang ada di dalam apresiasi karya sastra tersebut belum tentu dicapai secara menyeluruh oleh siswa. Variasi kemampuan dan pengetahuan siswa tentu menjadi salah satu faktor yang mempengaruhi pelaksanaanya. Untuk mencapainya secara utuh maka penentu kebijakan dan guru sebagai pelaksananya melakukan berbagai usaha yang bisa mendukung peningkatan apresiasi siswa tentunya dengan memaksimalkan proses pelaksanaannya.

Tahapan yang dilalui oleh siswa dalam pembelajaran sastra dapat membantunya untuk menemukan jawaban dari berbagai tugas dan masalah yang ditemukan. Proses membaca yang dilaksanakan secara terarah dan menjadi rutinitas bisa berfungsi sebagai alat utama pengembangan apresiasi. Kemampuan siswa akan semakin berkembang apabila didukung oleh kemauan dan kesadaran yang berasal dari siswa itu sendiri serta dukungan para guru. Hal itu sesuai dengan pernyataan "reader not only have knowledge, they have abilities: abilities not only learn new knowledge, but also abilities to process information" (Alderson, 2000, p.48) yang bermakna pembaca tidak hanya memiliki pengetahuan melainkan juga kemampuan, yakni kemampuan yang tidak hanya bertujuan untuk mempelajari pengetahuan yang baru melainkan juga kemampuan-kemampuan untuk memeroses informasi.

Manifestasi sastra sebagai salah satu gambaran kehidupan sosial masyarakat dinilai oleh Sujarwanto (Sujarwanto \& Jabrohim, 2002, p.514) sebagai wujud fakta historis yang berisi pemahaman manusia. Oleh karena itu, pendidikan sastra memiliki kedudukan yang penting dalam pembangunan kultural bangsa. Di samping itu, keberadaan sastra dalam kurikulum bahasa Indonesia memungkinkan dilakukannya pengkajian dan pengujian efek-efeknya pada diri siswa. Dengan kata lain, studi sastra menjadi 


\section{LingTera, 3 (1), May 2016 - 65 \\ Mimi Alpian, Maman Suryaman}

suatu eksplorasi terhadap motivasi dan respon siswa sebagai pembaca.

Seorang siswa yang menempuh jenjang pendidikan di sekolah menengah pertama (SMP) biasanya akan diberikan materi kesusastraan yang sesuai dengan ketentuan yang telah ditetapkan oleh pemerintah yakni berdasarkan standar kompetensi dan kompetensi dasar nasional. Jadi, kemampuan apresiasi sastra siswa dapat dilihat berdasarkan empat tingkat apresiasi yang dipaparkan sebelumnya, baik pada tingkat menggemari, menikmati, mereaksi, maupun mencipta. Sesuai dengan kedudukan sastra tersebut dalam pembelajaran bahasa, Jabrohim (1994, p.100) berpendapat jika "apresiasi lebih mengacu pada masalah sikap dan nilai dan dalam struktur kejiwaan manusia yang sikap dan nilai termasuk dalam ranah afektif".

Konsep tentang jenis bahan bacaan sastra dan tugas bersastra berhubungan dengan sebuah penjelasan yang disampaikan oleh Morton (2010, p.4) yang berbunyi "Reading literature standarts range from the ability in the early grades to retell stories with key details and describe characters and setting to the ability in the senior high grades to support analysis of the theme develops over the course of the text". Intinya adalah standar tugas membaca ataupun bentuk kegiatan apresiasi sastra pada jenjang sekolah menengah pertama masih pada tahap kemampuan menceritakan kembali karya sastra yang dibaca dengan menganalisis dan menggambarkan karakter tokoh dan latar yang ada. Selain itu, Nilsen \& Donelson (2009, p.12) menyebutkan: "anak-anak yang berada pada jenjang SMP memiliki kecenderungan untuk membaca buku pada tahap menemukan sendiri unsur-unsur yang membangun karya sastra dengan tema atau bentuk-bentuk karya sastra seperti fiksi-fiksi realistis, fiksi-fiksi kontemporer, dan cerita-cerita yang menggambarkan semangat atau perjuangan".

Jumlah buku bacaan sastra yang dianjurkan oleh para sastrawan untuk siswa SMP masih tergolong sedang. Hal itu sesuai dengan pendapat Ismail (2013) yang menjelaskan jika siswa setingkat SMP seharusnya diwajibkan membaca sembilan buku sastra dengan judul yang berbeda.

Untuk menjamin dan mendorong peningkatan siswa dalam pembelajaran sastra, pemerintah membuat peraturan khusus yang mengatur tentang pengembanagan kemampuan dan kebiasaan membaca dan menulis siswa. Peraturan pemerintah (PP) tersebut tercantum di dalam
Pasal 26 ayat 3 dimana disebutkan bahwa "kompetensi lulusan untuk mata pelajaran bahasa menekankan pada kemampuan membaca dan menulis yang sesuai dengan jenjang pendidikan" (Suryaman, 2009, p.43).

Teori-teori tentang apresiasi sastra yang telah dijabarkan menunjukkan jika apresiasi sastra merupakan sebuah istilah yang digunakan oleh peneliti untuk mengetahui tingkat apresiasi yang dimiliki oleh siswa, mulai dari tingkat menggemari, menikmati, mereaksi, dan mencipta karya sastra sendiri. Tingkatan apresiasi sastra siswa tersebut akan dilihat berdasarkan sikap siswa terhadap berbagai karya sastra yang ada karena apresiasi lebih mengacu pada sikap dan nilai yang kedua hal tersebut mengarah pada ranah (domain) afektif. Jadi, kegiatan apresiasi karya sastra dalam penelitian ini adalah sikap positif siswa terhadap karya sastra yang menumbuhkan keinginan mereka untuk menggemari, menikmati, mereaksi, dan mencipta karya sastra.

\section{Motivasi}

Ada beberapa pengertian yang dipergunakan untuk menjabarkan istilah motivasi. Wade \& Tavris $(2011$, p.431) mendefinisikan motivasi berdasarkan etimologinya, yakni "The word motivation, like the word emotion, comes from the Latin root meaning "to move" "motivasi diartikan berdasarkan asal katanya seperti halnya kata emosi, berasal dari bahasa Latin yang berarti bergerak. Makna harfiah dari kata bergerak bisa disimpulkan sebagai sesuatu yang terus mengalami perubahan, sesuai dengan situasi dan kondisi individu yang menjalaninya serta perkembangan zaman yang mengikutinya.

Hal yang sedikit berbeda disampaikan oleh Atkinson (Gredler, 1986, p.275) jika "motivation is a function of task variables and the individual's disposition to strive for succes or avoid failure" yang berarti motivasi adalah sebuah fungsi variabel tugas dan disposisi atau kecenderungan individu untuk memperjuangkan kesuksesan atau menghindari kesalahan.

Pendapat tentang definisi motivasi yang lain adalah "proses saat aktivitas-aktivitas yang berorientasi target dibuat terjadi dan dipertahankan kelangsungannya" (Schunk, 2012, p.58). Definisi tersebut diperkuat oleh pendapat Santrock (2011, p.510) yang menyatakan "motivasi sebagai proses memberi semangat, arah, dan kegigihan perilaku. Artinya, perilaku yang termotivasi adalah perilaku yang penuh energi, terarah dan bertahan lama". 


\section{LingTera, 3 (1), May 2016 - 66 \\ Mimi Alpian, Maman Suryaman}

Teori-teori para ahli tersebut mengindikasikan beberapa kata kunci yang diawali oleh makna harfiah (asal kata) dari motivasi itu sendiri yang diartikan sebagai gerakan, yang diikuti oleh target, semangat dan kegigihan. Dari beberapa kata tersebut bisa disimpulkan jika motivasi adalah sebuah desakan yang berbentuk gerakan karena adanya target, semangat yang tinggi dan usaha yang gigih untuk mencapainya. Dengan kata lain, motivasi mengindikasikan adanya gerakan atau perubahan tingkah laku yang dilakukan oleh seseorang karena ingin mencapai target atau tujuan tertentu sehingga menimbulkan semangat yang tinggi serta usaha yang gigih agar terget tersebut dapat dicapai dengan maksimal. Seorang ahli psikologi sastra yang bernama Escarpit (2008, p.138) menjelaskan jika motivasi membaca sastra yang dilakukan oleh seseorang dapat dilhat dari dua sisi, yakni motivasi psikologis dan motivasi yang berasal dari situasi materi yang melatari prilaku pembaca.

Motivasi psikologis yang dimiliki oleh seseorang berhubungan dengan alasan mental atau psikologis mereka untuk membaca sebuah karya sastra. Motivasi tersebut pada awalnya bisa saja sebuah motivasi hanya untuk mengoleksi buku, rasa hormat pada pengarang, untuk mengobati rasa kantuk dan lain sejenisnya. Oleh sebab itu, motivasi psikologis ini dikaitkan dengan motivasi fungsional membaca dan motivasi sastra. Motivasi fungsional lebih kepada membaca sebagai sarana untuk memeroleh rasa yang lebih baik atau dijadikan sebagai obat penghilang rasa jenuh, obat menghilangkan stres dan obat agar bisa mengantuk. Motivasi sastra lebih kepada motivasi untuk menghormati kenetralan karya sastra dan tidak menjadikan apresiasi sastra sebagai alat melainkan tujuan.

\section{Keyakinan Diri}

Bandura (Friedman \& Schustack, 2008, p.283) menyebutkan bahwa "keyakinan diri adalah ekspektasi-keyakinan (harapan) tentang seberapa jauh seseorang mampu melakukan satu perilaku dalam suatu situasi tertentu". Pendapat lainnya menyebutkan jika "keyakinan diri adalah keyakinan seseorang bahwa dirinya mampu meraih hasil yang diinginkan, seperti penguasaan suatu keterampilan baru atau mencapai suatu tujuan" (Wade \& Tavris, 2007, p.180). Pendapat-pendapat para ahli terkait keyakinan diri tersebut menunjukkan bahwa keyakinan diri memiliki peranan yang cukup penting untuk mencapai tujuan seseorang.
Pendapat yang sama juga diungkapkan oleh Woolfolk (2007, p.392) "Self-efficacy is our belief about our personal competence or effectiveness in a given area and important variable for students to monitor. Intinya adalah keyakinan diri sebagai kepercayaan yang bisa mendorong atau mengarahkan seseorang untuk menemukan solusi dalam sebuah situasi dan mampu menghasilkan sikap positif dari situasi yang terjadi. Dengan kata lain, keyakinan diri menjadi kunci dan stimulus utama yang bisa membantu seseorang menemukan solusi atau jalan keluar dari sebuah situasi yang sedang dihadapi.

Ada banyak manfaat keyakinan diri, di antaranya yang diungkapkan Hackett (Bandura, 1997, p.244) yaitu: "self-efficacy theory is that it provides guidelines for intervening to correct detrimental self-beliefs. That is the four major sources of efficacy information - performance accomplishments, vicarious learning, physiological arousal and affective states, and verbal persuasion" Pendapat tersebut menjelaskan jika keyakinan diri berfungsi sebagai pedoman seseorang untuk memperbaiki mental keyakinan diri. Keyakinan diri tersebut memiliki empat sumber utama yakni pembelajaran yang diperoleh dari kehidupan yang telah dijalani, faktor psikologi yang berhubungan dengan mental, pikiran dan perasaan, berikutnya adalah keinginan untuk lebih baik, dan yang terakhir adalah bujukan atau rayuan yang berasal dari orang lain.

Friedman \& Schustack (2008, p.283) menyebutkan jika keyakinan diri adalah hasil dari empat jenis informasi, yaitu: (1) pengalaman dalam melakukan prilaku yang diharapkan atau prilaku yang serupa; (2) melihat orang lain melakukan prilaku tersebut atau prilaku yang kurang lebih sama membandingkan pengalaman yang sama pada individu atau orang yang berbeda (vicarious experience); (3) persuasi verbal (bujukan orang lain yang bertujuan untuk menyemangati atau menjatuhkan performa); dan (4) apa perasaan kita tentang prilaku yang dimaksud bagaimana respon kita tentang prilaku yang dimaksud (reaksi emosional). Dari keempat informasi tersebut, pengalaman pribadi adalah sumber informasi terpenting.

Keyakinan diri sangat penting untuk dikembangkan karena seseorang yang memiliki keyakinan diri yang kuat akan dapat mengatasi berbagai rintangan atau tantangan yang dihadapi dengan baik. Wade \& Tavris (2007, p.180) mengungkapkan bahwa "individu-individu yang 


\section{LingTera, 3 (1), May 2016 - 67 \\ Mimi Alpian, Maman Suryaman}

memiliki keyakinan diri yang kuat adalah individu-individu yang dapat beradaptasi secara cepat pada permasalahan yang mereka hadapi, dan tidak menjadi cemas atau panik menghadapi permasalahan-permasalahan tersebut." Jadi, Keyakinan diri dalam penelitian ini adalah keyakinan terhadap kemampuan yang dimiliki untuk mengatur diri dan bertahan pada berbagai situasi dan kondisi dalam pembelajaran apresiasi sastra sehingga mampu meraih kesusksesan dan menyelesaikan setiap tugas yang diberikan sesuai dengan waktu yang telah ditetapkan.

\section{Persepsi Siswa}

Pengertian persepsi atau perception dalam kamus ilmiah (Partanto \& Barry, p.2001) adalah "pengamatan, penyusunan dorongan-dorongan dalam kesatuan-kesatuan, hal mengetahui, melalui indera tanggapan (indera) dan daya memahami". Oleh karena itu, kemampuan manusia untuk membedakan, mengelompokkan dan memfokuskan yang ada di lingkungan sekitar mereka disebut sebagai kemampuan untuk mengorganisasikan pengamatan atau persepsi.

Devidoff (1980, p.127) mengemukakan pendapat tentang persepsi seperti berikut ini: "perseption is a cognitive process are interconnected. We are beginning our survey of cognition with perception because perception is the point where cognition and reality meet and perhap the most basic kognitive activity out of which all other emerge". Persepsi adalah sebuah proses kognitif yang saling berhubungan. Survei tentang kognisi dengan persepsi dimulai karena persepsi merupakan butir yang kognisi dan realitas serta kemungkinan lebih banyak aktivitas kognitif dasar yang bermunculan. Oleh sebab itu, persepsi secara khusus didefinisikan sebagai "the process of organizing and interpreting incoming sensory data (sensation) to develop an awareness of surrounding and self', proses mengorganisasi dan menginterpretasi data sensorik untuk mengembangkan sebuah kesadaran dan kepribadian sebagai individu.

Menurut Atkinson, Atkinson, \& Hilgard (1987, p.277) "persepsi adalah penelitian bagaimana seseorang mengintegrasikan sensori ke dalam perspektif objek dan bagaimana seseorang selanjutnya menggunakan perspektif itu untuk mengenali dunia". Pendapat lain diungkapkan oleh Schunk (2012, p.244) bahwa "persepsi mengacu pada pelekatan makna pada input-input lingkungan yang diterima melalui pancaindera".

Secara garis besar, persepsi adalah pemberian makna terhadap input atau respon yang diterima oleh seseorang yang makna tersebut dipengaruhi oleh pengetahuan dan pengalaman yang dimiliki. Untuk mendapatkan hasil yang positif dari persepsi yang sebenarnya dimiliki oleh siswa itu sendiri maka pengetahuan dan pengalaman yang dibangun pada tahap pengenalan dan pembelajaran objek atau materi yang terkait harus bersifat positif pula. Dari sana bisa dilihat jika persepsi memiliki hubungan yang erat dengan pemberian makna dari seorang siswa sebagai individu terhadap karya sastra yang ditemukan, baik di lingkungan sekolah maupun masyarakat umum.

\section{METODE}

Penelitian ini menggunakan pendekatan kuantitatif dengan metode survei. Desain penelitian yang akan digunakan peneliti seperti Gambar 1 berikut ini.

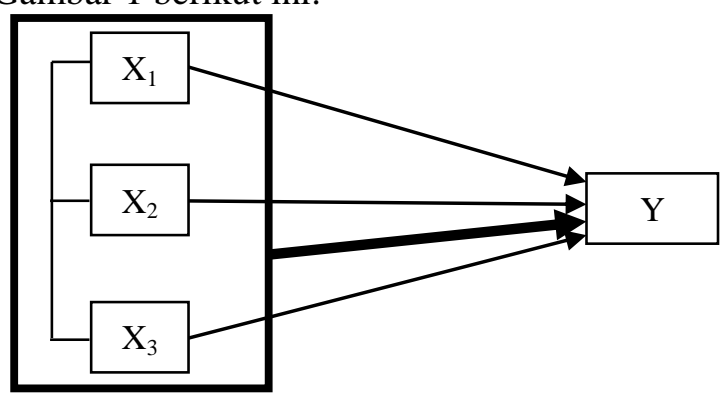

Gambar 1. Desain Penelitian

$\mathrm{X}_{1}, \mathrm{X}_{2}, \mathrm{X}_{3}$ adalah variabel bebas (motivasi, keyakinan diri, dan persepsi siswa) dan $\mathrm{Y}$ adalah variabel terikat yaitu apresiasi karya sastra. Instrumen pengumpulan data dalam penelitian ini adalah: (1) angket apresiasi karya sastra, (2) angket motivasi, (3) angket keyakinan diri, dan (4) angket persepsi siswa.

\section{Teknik Analisis Data}

\section{Analisis Deskripsi}

Data yang berupa skor apresiasi karya sastra, motivasi, keyakinan diri, dan persepsi siswa yang diperoleh dianalisis menggunakan statistik deskriptif untuk mendapatkan nilai ratarata, varian dan standar deviasi.

Skor yang diperoleh kemudian dikonversikan menjadi data kualitatif skala lima, dengan acuan rumus yang dikutip dari acuan rumus yang diadaptasi dari Azwar (2012, p.163) yang disajikan pada Tabel 2. 
Tabel 2. Konversi Skor Aktual Menjadi Nilai Skala Lima

\begin{tabular}{cc}
\hline Interval Skor & Kriteria \\
\hline $\mathrm{Mi}+1,5 \mathrm{SDi}<\mathbf{X} \leq \mathbf{M i}+\mathbf{3 S D i}$ & Sangat tinggi \\
$\mathrm{Mi}+0,5 \mathrm{SDi}<\mathbf{X} \leq \mathbf{M i}+\mathbf{1 , 5} \mathbf{S D i}$ & Tinggi \\
$\mathrm{Mi}-0,5 \mathrm{SDi}<\mathbf{X} \leq \mathbf{M i}+\mathbf{0 , 5 S D i}$ & Sedang \\
$\mathrm{Mi}-1,5 \mathrm{SDi}<\mathbf{X} \leq \mathbf{M i}-\mathbf{0 , 5}$ SDi & Rendah \\
Mi-3SDi $\leq \mathbf{X} \leq \mathbf{M i}-\mathbf{1 , 5}$ SDi & Sangat Rendah \\
\hline
\end{tabular}

Keterangan:

$\mathrm{Mi}=$ rerata skor ideal $=\frac{1}{2}$ (skor maksimum ideal + skor minimum ideal)

SDi $=$ Standar Deviasi ideal $=\frac{1}{6}$ (skor maksimum ideal - skor minimum ideal)

$\mathrm{X}=$ Total skor aktual

\section{Analisis Regresi Ganda}

Asumsi yang harus dipenuhi dalam analisis regresi ganda yaitu multikolinieritas, heteroskedastisitas, normalitas, dan autokorelasi. Teknik analisis regresi linier ganda dengan tiga variabel bebas menggunakan taraf signifikansi 0,05 dengan persamaan sebagai berikut.

$\hat{Y}=\beta_{\mathrm{o}}+\beta_{1} \mathrm{X}_{1}+\beta_{2} \mathrm{X}_{2}+\beta_{3} \mathrm{X}_{3}+\varepsilon$

Keterangan :

$\hat{Y}=$ Apresiasi Karya Sastra

$\beta_{0}=$ konstanta regresi

$\beta_{1}=$ koefisien motivasi

$\beta_{2}=$ koefisien keyakinan diri

$\beta_{3}=$ koefisien persepsi siswa

$\varepsilon=$ faktor error

Model regresi linier dapat digunakan atau tidak, maka diuji menggunakan uji Anava dengan rumus sebagai berikut:

$$
F=\frac{R^{2} / k}{\left(1-R^{2}\right) /(n-k-1)} \text { dengan } k \text { dan }(n-k-1) d f
$$

(Steven, 2009, p.72)

Untuk mengetahui apakah ada pengaruh setiap variabel bebas terhadap variabel terikat digunakan uji parsial dengan uji-t sebagai berikut:

$$
\mathrm{t}=\frac{b_{j}}{\operatorname{s.e}\left(b_{j}\right)}
$$

\section{HASIL PENELITIAN}

\section{Analisis Deskriptif}

Deskripsi variabel responden atau sampel penelitian meliputi hasil penghitungan nilai ratarata, varian, simpangan baku, skor terendah, dan skor tertinggi untuk mengetahui gambaran serta hasil penghitungan statistiknya secara umum. Deskripsi hasil penghitungan data yang diperoleh dari responden tersebut menunjukkan nilai yang berbeda dari setiap butir data yang dianalisis. Hasil penghitungan pertama menunjukkan rata-rata hitung keseluruhan responden yang mengindikasikan nilai rata-rata yang mengacu pada skor masing-masing individu dan jumlah keseluruhan responden. Kedua, hasil yang ada di dalam tabel menggambarkan nilai varian yang dimaknai sebagai simpangan baku kuadrat. Ketiga, deskripsi hasil tersebut menunjukkan nilai simpangan baku (standar deviasi) yang mengindikasikan ukuran variabilitas (penyebaran) skor yang didasarkan pada kuadrat penyimpangan tiap skor dari rata-rata hitung (Nurgiyantoro, 2009, p.73). Keempat, hasil penghitungan di dalam tabel tersebut menunjukkan nilai atau skor terendah yang dihasilkan oleh responden yang digambarkan secara umum dari keseluruhan nilai atau skor tiap-tiap responden, begitu pula yang kelima walaupun yang digambarkan adalah hasil nilai maksimal yang diperoleh dari keseluruhan responden. Untuk memperjelas hasil penghitungan data yang telah digambarkan di dalam tabel, selanjutnya akan dideskripsikan setiap nilai yang diperoleh.

Berikut ini disajikan rangkuman hasil deskripsi variabel responden atau sampel penelitian.

Tabel 3. Deskripsi Variabel Responden Siswa SMP di Kabupaten Lombok Timur

\begin{tabular}{ccccc}
\hline Hasil Penghitungan dari & Apresiasi Karya Sastra & Motivasi & Keyakinan Diri & Persepsi Siswa \\
\hline Rata-rata & 42,76 & 52,07 & 34,33 & 55,24 \\
Varian & 42,16 & 80,18 & 35,94 & 63,26 \\
Simpangan Baku & 6,49 & 8,95 & 5,99 & 7,95 \\
Skor Terendah & 28,00 & 25,00 & 17,00 & 19,00 \\
Skor Tertinggi & 60,00 & 76,00 & 54,00 & 87,00 \\
\hline
\end{tabular}




\section{LingTera, 3 (1), May 2016 - 69 \\ Mimi Alpian, Maman Suryaman}

\section{Analisis Regresi dan Pembahasan}

Keberhasilan pembelajaran akan terlihat ketika semua proses dan hasil bisa diperoleh secara maksimal. Pembelajaran bahasa tidak hanya menekankan pada aspek kognitif yang menilai dan mengevaluasi pengetahuan siswa tentang berbagai konsep berbahasa dan bersastra yang semestinya harus dimiliki. Sumber-sumber dan berbagai informasi tentang keberhasilan proses pembelajaran bahasa Indonesia yang terjadi di wilayah tertentu bisa diperoleh dari berbagai informasi yang telah disediakan oleh lembaga pemerintah secara formal. Hal itu tentu dilakukan agar semua pihak bisa melakukan evaluasi atau penilaian bahkan penelitian dengan terjun langsung ke lapangan sehingga diperoleh berbagai masukan yang berguna dalam meningkatkan mutu pendidikan.

Data dan fakta yang terjadi di Kabupaten Lombok Timur menunjukkan jika keberhasilan pembelajaran bahasa Indonesia, khususnya yang terkait dengan materi bersastra belum maksimal. Berdasarkan penghitungan Coefficient korelasi yang diperoleh dari hasil analisis data yang telah dilaksanakan maka bisa ditentukan model regresi seperti berikut ini.

Persamaan atau model regresi dari hasil penelitian adalah sebagai berikut:

$\hat{Y}=11,390+0,265 X_{1}+0,332 X_{2}+0,111 X_{a}$

$\hat{Y}$ adalah apresiasi karya sastra siswa sedangkan $X_{1}$ adalah motivasi siswa, $X_{2}$ adalah keyakinan diri siswa, dan $X_{3}$ adalah persepsi siswa.

Hasil tersebut dapat dijabarkan sebagai berikut: Pertama, konstanta sebesar 11,390 menyatakan bahwa jika tidak ada motivasi, keyakinan diri dan persepsi, maka apresisasi karya sastra siswa adalah 11,390; Kedua, koefisien regresi $X_{1}$ (motivasi siswa) sebesar 0,265 menyatakan bahwa setiap penambahan (makna penambahan ditandai oleh +) 1 nilai/skor apresiasi karya sastra bertambah 0,265. Akan tetapi, hal yang sebaliknya akan terjadi jika motivasi siswa mengalami penurunan sebesar 1 , maka apresiasi karya sastra juga diprediksi mengalami penurunan sebesar 0,265. Jadi, tanda + (plus) melambangkan arah hubungan yang searah yang kenaikan atau penurunan variabel motivasi $\left(X_{1}\right)$ akan mengakibatkan kenaikan atau penurunan variabel dependen (Y) yakni apresiasi karya sastra.

Koefisien regresi $X_{2}$ (keyakinan diri siswa) sebesar 0,332 mengindikasikan bahwa setiap penambahan (makna penambahan ditandai oleh +) 1 nilai/skor apresiasi karya sastra bertambah 0,332. Namun, hal yang sebaliknya akan terjadi jika keyakinan diri siswa mengalami penurunan sebesar 1, maka apresiasi karya sastra juga diprediksi mengalami penurunan sebesar 0,332. Jadi, tanda + (plus) menyatakan arah hubungan yang searah, yang kenaikan atau penurunan variabel keyakinan diri $\left(X_{2}\right)$ akan mengakibatkan kenaikan atau penurunan variabel dependen $(\mathrm{Y})$ yakni apresiasi karya sastra.

Koefisien regresi $X_{3}$ (persepsi siswa) sebesar 0,111 menyatakan bahwa setiap penambahan (makna penambahan ditandai oleh +) 1 nilai/skor apresiasi karya sastra bertambah 0,111 . Akan tetapi, hal yang sebaliknya akan terjadi jika persepsi siswa mengalami penurunan sebesar 1, maka apresiasi karya sastra juga diprediksi mengalami penurunan sebesar 0,111. Jadi, tanda + (plus) melambangkan arah hubungan yang searah, yang kenaikan atau penurunan variabel persepsi siswa $\left(X_{2}\right)$ akan mengakibatkan kenaikan atau penurunan variabel dependen (Y) yakni apresiasi karya sastra. Penambahan dan pengurangan nilai yang bisa diketahui dari persamaan regresi tersebut pada dasarnya memiliki kesesuaian dengan kondisi Kabupaten Lombok Timur yang menjadi salah satu bagian dari provinsi Nusa Tenggara Barat yang masih memiliki tingkat pendidikan dan IPM yang tergolong rendah.

Rendahnya pengetahuan siswa tentang bahasa Indonesia, khususnya tentang sastra menjadi sebuah fenomena yang terjadi hingga saat ini bisa dilihat dari hasil ujian nasional. Kondisi itu tentu saja menggambarkan jika siswa belum mampu menyeimbangkan pengetahuan yang dimiliki secara proporsional. Faktorfaktor yang mengakibatkan hal tersebut tentu dipengaruhi oleh berbagai hal yang berasal dari siswa itu sendiri, guru, kurikulum, sarana dan prasarana serta berbagai hal yang terjadi bahkan interaksi di sekitar lingkungan.

Motivasi siswa SMP di Kabupaten Lombok Timur menunjukkan bahwa nilai signifikansinya sebesar 0,000 sehingga dihasilkan jika $\mathrm{H}_{\mathrm{o}}$ ditolak atau dapat dikatakan motivasi berpengaruh terhadap apresiasi karya sastra siswa SMP di Kabupaten Lombok Timur. Motivasi yang dimaksud disini adalah motivasi sebagai proses yang memberi semangat, arah, dan kegigihan perilaku. Artinya, perilaku yang termotivasi adalah perilaku yang penuh energi, terarah dan bertahan lama (Santrock, 2011, p.510). Secara spesifik motivasi dalam penelitian ini 


\section{LingTera, 3 (1), May 2016 - 70 \\ Mimi Alpian, Maman Suryaman}

dibatasi pada pengertian motivasi sebagai sebuah desakan yang berbentuk gerakan karena adanya target, semangat yang tinggi, dan usaha yang gigih untuk mencapainya. Kondisi real yang terjadi di lapangan yang diungkapkan oleh para guru adalah siswa cukup sulit untuk didorong dan melaksanakan tugas-tugas yang berkaitan dengan apresiasi sastra. Secara umum, kondisi tersebut pada dasarnya tidak hanya terjadi pada materi bersastra saja melainkan juga materi pembelajaran bahasa Indonesia yang lain.

Pada kenyataannya meskipun guru telah berupaya untuk mengarahkan siswa melakukan kegiatan apresiasi sastra di luar kelas namun mereka lebih sering memanfaatkan itu untuk sekadar bermain dan tidak terlalu dianggap serius. Kenyataan menarik lainnya yang ditemukan di lapangan yang memiliki hubungan dengan motivasi siswa dalam melakukan kegiatan apresiasi sastra sastra yakni siswa cenderung menganggap bahwa orang-orang yang bersastra atau melakukan kegiatan apresiasi sastra "lucu" yang identik dengan lawakan atau entertain semata yang tidak memiliki amanat atau pelajaran yang bisa diambil dari proses pelaksanaannya. Keadaan itu terbukti ketika peneliti meminta salah seorang siswa untuk membaca salah satu puisi di depan kelas dan ternyata siswa yang lain menanggapi kegiatan pembacaan puisi tersebut sebagai sebuah kegiatan yang kurang menarik dan hanya ditertawakan (ditanggapi dengan tidak serius). Kondisi tersebut ditemukan pada salah satu sekolah yang ada di wilayah batas kota atau kecamatan.

Hal inilah yang menjadi salah satu dasar jika keyakinan diri dan motivasi siswa SMP di Kabupaten Lombok Timur dalam apresiasi karya sastra harus ditingkatkan begitu pula persepsi siswa tidak bisa diabaikan. Untuk mencapai semua tersebut tentu dibutuhkan perhatian semua pihak, terutama para guru agar benar-benar membantu dan mengarahkan siswa untuk lebih peka dan paham terhadap berbagai kegiatan sastra yang ada tentunya dengan memberikan teladan sekaligus pengertian jika kegiatan apresiasi sastra itu menyenangkan dan bisa memperluas wawasan.

Keyakinan diri siswa SMP di Kabupaten Lombok Timur menghasilkan nilai signifikansi sebesar 0,000 maka $\mathrm{H}_{\mathrm{o}}$ ditolak atau dapat dikatakan keyakinan diri berpengaruh terhadap apresiasi karya sastra siswa SMP di Kabupaten Lombok Timur. Untuk menguatkan keyakinan diri mempunyai peran yang sangat penting dapat dilihat dari hasil penelitian yang dilakukan oleh
Anwar (2009) yang menghasilkan kesimpulan semakin tinggi keyakinan diri siswa tingkat kecemasan berbicara di depan umum semakin rendah. Hal lain yang menguatkan pentingnya keyakinan diri adalah pendapat dari Zimmerman (Bandura, 1997, p.203) yang menyatakan jika "keyakinan diri bisa membantu seseorang individu atau seseorang pada berbagai situasi yang tentunya tidak terbatas pada kondisi tertentu dan kurangnya keyakinan diri bisa membunuh keahlian atau skill yang dimiliki oleh seseorang".

Sumbangan yang signifikan dari keyakinan terhadap apresiasi karya sastra siswa SMP disebabkan karena adanya keyakinan akan kemampuan diri dalam belajar sastra yang disertai dengan keyakinan bahwa segala peristiwa dalam hidupnya ditentukan oleh usaha dan perilakunya sendiri. Hal tersebut pada gilirannya akan mendorong individu untuk mengarahkan segala tenaga, usaha, dan perilakunya untuk mencapai kematangan karir yang diharapkan.

Persepsi siswa SMP di Kabupaten Lombok Timur menghasilkan nilai signifikansi sebesar 0,001 maka $\mathrm{H}_{\mathrm{o}}$ ditolak atau dapat dikatakan persepsi siswa berpengaruh terhadap apresiasi karya sastra siswa SMP di Kabupaten Lombok Timur. Hasil penghitungan statistik tersebut secara umum mengindikasikan bahwa selain faktor motivasi, keyakinan diri dan persepsi siswa terhadap beberapa faktor lain yang turut mempengaruhi apresiasi karya sastra. Adapun pengertian persepsi menurut Schunk (2012, p.244) adalah "pelekatan makna pada input-input lingkungan yang diterima melalui pancaindera". Secara spesifik, pengertian persepsi dari penelitian yang dilakukan ini sesuai dengan pendapat beberapa ahli adalah pemberian makna pada input atau respon yang diterima oleh seseorang yang makna tersebut dipengaruhi oleh pengetahuan dan pemahaman yang dimiliki.

Keterangan berupa hasil wawancara dengan beberapa siswa pada dasarnya seimbang dengan hasil analisis statistik yang menunjukkan jika persepsi siswa terhadap apresiasi karya sastra memiliki pengaruh positif. Secara umum, siswa menganggap kegiatan apresiasi sastra tidak terlalu penting dibanding dengan kegiatan yang lain ditambah lagi dengan kurangnya informasi terkait dengan beberapa sanggar sastra yang biasa melakukan berbagai kegiatan antarsekolah. Keadaan tersebut tentu juga diakibatkan oleh pemahaman siswa terhadap sastra yang bisa dikatakan sangat sempit. Pendapat tersebut 


\section{LingTera, 3 (1), May 2016 - 71 \\ Mimi Alpian, Maman Suryaman}

dimunculkan karena sebagian besar siswa yang ditanya tentang istilah dan makna sastra serta kegiatan sastra yang diketahui ternyata rata-rata menjawab tidak tahu dan hanya mengenal beberapa teori atau konsep yang menjadi bagian dari ujian nasional dan sengaja ditekankan pembelajarannnya oleh guru. Materi-materi yang dimaksud umumnya berhubungan dengan unsur-unsur intrinsik dan ekstrinsik yang ada di dalam karya sastra.

Penelitian terkini yang dilakukan oleh Subarna Sivapalan, Hairuzila Idrus, Ena Bhattacharyya, dan SM Mordin dari Universitas Teknologi PETRONAS yang berjudul "engineering students perception of the influence of young adult literature on develoving apreciation for reading" menunjukkan bahwa persepsi siswa memiliki peran yang penting dalam mengembangkan kemampuan apresiasi siswa dan guru serta untuk meningkatkan skill atau kemampuan membaca dan menulisnya.

Penghitungan hasil penelitian dari data yang telah diperoleh menunjukkan jika nilai $\mathrm{F}$ hitung yang diperoleh dari hasil uji ANAVA atau $F$ tes sebesar 105,252 dengan signifikansi 0.000. Berdasarkan hasil tersebut bisa dilihat jika signifikansi jauh lebih kecil dari 0.05, maka $\mathrm{H}_{0}$ ditolak atau dapat dikatakan bahwa motivasi, keyakinan diri dan persepsi siswa secara bersama-sama berpengaruh terhadap apresiasi karya sastra siswa. Besarnya indeks korelasi ganda kuadrat $\left(\mathrm{R}^{2}\right)$ adalah 0.454 , hal ini berarti $45,4 \%$ variasi apresiasi karya sastra siswa dapat dijelaskan oleh variasi dari ketiga variabel independen motivasi siswa, keyakinan diri siswa dan persepsi siswa. Sisanya $(100 \%-45,4 \%=54.6 \%)$ dijelaskan oleh sebab-sebab yang lain di luar variabel independen.

Indeks korelasi ganda kuadrat $\left(\mathrm{R}^{2}\right)$ tersebut menggambarkan lebih dari $45 \%$ kontribusi motivasi, keyakinan diri dan persepsi siswa terhadap apresiasi karya sastra siswa, sehingga tingginya motivasi, keyakinan diri dan persepsi menentukan apresiasi karya sastra siswa. Oleh karena itu, motivasi, keyakinan diri dan persepsi siswa perlu ditingkatkan.

Sumbangan terbesar terhadap apresiasi karya sastra siswa SMP di Kabupaten Lombok Timur, yaitu variabel keyakinan diri setelah itu diikuti oleh motivasi dan persepsi. Hal tersebut ditunjukkan oleh koefisien regresi pada variabel keyakinan diri sebesar 0,332 dan motivasi siswa sebesar 0,265 serta persepsi sebesar 0,111. Hasil tersebut dikuatkan oleh penelitian yang dilakukan oleh Nicole A. Mill dari University of
Pennsylvania dengan judul "teaching assistants self efficacy inteaching literature: Source, personal assessment, and consequences" yang dilaksanakan pada tahun 2011 dan menghasilkan jika keyakinan diri dibutuhkan dalam pembelajaran apresiasi sastra, baik oleh guru maupun siswa. Hasil penelitian ini mengindikasikan jika keyakinan diri memiliki pengaruh juga terhadap apresiasi karya sastra yang dilakukan oleh siswa. Untuk itu, perlu dilakukan kajian yang mendalam dengan melihat seberapa besar pengaruh keyakinana diri yang dimiliki oleh siswa dalam melaksanakan kegiatan apresiasi sehingga bisa dilakukan langkah antisipatif atau pencegahan dan perbaikan berdasarkan situasi dan kondisi yang di temukan di lapangan.

Tingginya sumbangan keyakinan diri siswa terhadap apresiasi karya sastra tentunya dipengaruhi oleh beberapa faktor yang turut berperan dalam proses pembelajaran. Berdasarkan hasil wawancara sederhana dengan beberapa siswa yang ada di beberapa sekolah di Kabupaten Lombok Timur diperoleh informasi jika pengetahuan mereka terhadap sastra tidak terlalu maksimal. Keadaan tersebut disebabkan oleh kurangnya penjelasan atau pemberian pemahaman yang disampaikan oleh guru kepada siswa. Kondisi tersebut disebabkan juga oleh kuantitas waktu yang diberikan kepada siswa untuk memeraktikkan langsung berbagai bentuk karya sastra yang telah atau sedang dipelajari.

Data yang diperoleh dari siswa selanjutnya dikonfirmasi pada beberapa guru dengan mengadakan wawancara sederhana kembali tanpa berpatokan pada pedoman namun tetap beracuan pada tema utama penelitian yang berkaitan dengan apresiasi sastra siswa di setiap sekolah yang diteliti. Hasil wawancara tersebut menunjukkan jika guru telah berupaya memberikan pemahaman secara maksimal. Akan tetapi, proses pembelajaran yang diberikan kepada siswa ternyata tidak didukung oleh kondisi ketersedian fasilitas pembelajaran yang bisa dijadikan sebagai rujukan langsung oleh guru dan siswa terlebih beberapa waktu telah terjadi beberapa perubahan kurikulum yang mengakibatkan guru kesulitan menemukan buku pegangan yang tepat unruk pembelajaran sastra. Di luar itu, rata-rata semua sekolah yang ada di Kabupaten Lombok Timur tidak memiliki koleksi buku sastra yang memadai meskipun sekolah tersebut termasuk salah satu sekolah favorit yang ada di lingkungan atau wilayah kota kabupaten. 


\section{LingTera, 3 (1), May 2016 - 72 \\ Mimi Alpian, Maman Suryaman}

Penelitian ini menggunakan sampel yang diambil secara random berdasarkan akreditasi sekolah, sebaran penduduk dan sebaran wilayah sehingga perlu analisis tambahan untuk menguatkan hasil penelitian. Dari hasil analisis tambahan berupa uji beda yang sangat penting adalah tidak terdapat perbedaan yang signifikan dalam apresiasi karya sastra antarsekolah yang berada pada wilayah yang berbeda geografisnya. Dalam hal ini, wilayah dibagi menjadi tiga yaitu pertama wilayah pegunungan/pesisir/pedesaan, kedua wilayah kota kecamatan dan terakhir wilayah batas kota kecamatan. Selain itu, perbedaan tingkat akreditasi yang diraih oleh setiap sekolah juga tidak memberikan pengaruh yang tinggi terhadap kegiatan apresiasi karya yang dilakukan oleh siswa yang ada di wilayah Kabupaten Lombok Timur. Hal ini terbukti dari hasil analisis yang didapatkan tidak terdapat perbedaan yang signifikan dalam apresiasi karya sastra antara sekolah akreditasi A, B, ataupun C.

Analisis berikutnya adalah uji beda dengan mengelompokkan sampel berdasarkan sebaran jumlah penduduk yang ada pada Tabel 2. Analisis statistik menunjukkan bahwa tidak terdapat perbedaaan apresiasi karya sastra siswa antara siswa pada kategori sebaran penduduk tinggi, sedang, ataupun rendah. Keteranganketerangan tersebut mengindikasikan jika motivasi, keyakinan diri dan persepsi siswa yang ada di perkotaan, batas kota, pedesaan, pegunungan maupun pesisir relatif sama. Pendapat tersebut sesuai dengan hasil penghitungan uji beda dari berdasarkan akreditasi sekolah, sebaran wilayah, dan sebaran penduduk.

Rendahnya pengetahuan dan minimnya apresiasi karya sastra yang dilakukan oleh siswa ternyata berdampak pula pada rendahnya nilai siswa pada ujian nasional, khususnya pada materi yang terkait dengan apresiasi karya sastra. Dari sana bisa dilihat jika faktor motivasi, keyakinan diri, dan persepsi siswa memiliki pengaruh terhadap apresiasi karya sastra. Untuk memperbaiki dan mengembalikan pembelajaran sastra sesuai dengan apa yang diharapkan maka siswa harus diberikan rangsangan yang bisa mendorong motivasi mereka untuk melaksanakan apresiasi karya sastra. Di samping itu, dibutuhkan pula usaha yang mendorong penguatan keyakinan siswa untuk berbagai hal yang berhubungan dengan apresiasi karya sastra, mulai dari menikmati, menggemari, mereaksi sampai bagaimana mencipta sendiri karya sastra. Selain itu, diberikan teori yang menunjang dan bisa mengubah persepsi mereka terhadap apresiasi karya sastra itu sendiri yang pada dasarnya sangat menyenangkan dan meningkatkan pengetahuan.

\section{SIMPULAN DAN SARAN}

\section{Simpulan}

Berdasarkan data yang dikumpulkan dan hasil analisis yang telah dikemukakan maka dibuat kesimpulan sebagai berikut. (1) motivasi berpengaruh terhadap apresiasi karya sastra siswa SMP di Kabupaten Lombok Timur; (2) keyakinan diri berpengaruh terhadap apresiasi karya sastra siswa SMP di Kabupaten Lombok Timur; (3) persepsi siswa berpengaruh terhadap apresiasi karya sastra siswa SMP di Kabupaten Lombok Timur; (4) berdasarkan uji anava didapatkan motivasi, keyakinan diri dan persepsi siswa secara bersama-sama berpengaruh terhadap apresiasi karya sastra siswa SMP di Kabupaten Lombok Timur.

\section{Saran}

Para penentu kebijakan khususnya dinas pendidikan yang ada di Kabupaten Lombok Timur lebih meningkatkan lagi perhatiannya terhadap permasalahan yang dihadapi oleh sekolah-sekolah SMP yang ada terutama yang berhubungan dengan ketersedian buku bacaan sastra. Ketersedian buku yang mencukupi pada umumnya akan lebih meningkatakan motivasi siswa dalam apresiasi karya sastra.

Guru diharapkan lebih kreatif dan inovatif dalam membantu siswa untuk memahami berbagai karya sastra yang ada sekaligus lebih terarah untuk membimbing siswa dalam melakukan berbagai apresiasi karya sastra. Di samping itu, guru juga diharapkan membantu siswa untuk lebih tersadar akan kedudukan dan fungsi bahasa Indonesia sehingga siswa merasa termitivasi, yakin, dan memiliki persepsi yang positif terhadap bahasa Indonesia itu sendiri terlebih dengan berbagai kegiatan apresiasi sastra.

Para siswa diharapkan untuk lebih aktif dalam mencari informasi yang berhubungan dengan apresiasi karya sastra malalui pemanfaatan berbagai sumber yang tersedia, baik buku pelajaran, koran, majalah, buku sastra terlebih media internet. Hal itu tentu akan membantu siswa dalam berbagai hal terutama dalam menghadapi kehidupan dan berbagai ujian formal yang diselenggarakan.

Kepada peneliti selanjutnya, diharapkan melakukan penelitian lanjutan terkait temuan yang ada dalam penelitian ini sehingga bisa 


\section{LingTera, 3 (1), May 2016 - 73}

Mimi Alpian, Maman Suryaman

membantu dalam mengatasi permasalahan yang terjadi dalam apresiasi karya sastra.

\section{DAFTAR PUSTAKA}

Alderson, J.C. (2000). Assesing reading. New York, NY: Cambridge university press

Aminuddin. (2011). Pengantar apresiasi karya sastra. Bandung: Sinar Baru Algesindo

Anshori, D.S. \& Sumiyadi (ed). (2009). Bahasa dan sastra dalam perspektif pendidikan. Bandung: Percetakan Jurusan Pendidikan Bahasa dan Sastra Indonesia FPBS UPI

Anwar, A.I.D. (2009), Hubungan antara selfefficacy dengan kecemasan berbicara di depan umum pada mahasiswa fakultas psikologi Universitas Sumatra Utara. Tesis magister tidak diterbitkan, Universitas Sumatra Utara, Sumatra Utara

Atkinson, R.L., Atkinson, R.C., \& Hilgard, E.R. (1987). Pengantar psikologi jilid II. Batam: Interaksa

Azwar, S. (2012). Tes prestasi, fungsi dan pengembangan pengukuran prestasi belajar. Yogyakarta: Pustaka Pelajar Offset

Bandura, A (ed) (1997). Self-efficacy in changing societies. New York: Cambridge University Press

Darmono, S.D. (1979). Sosiologi sastra (sebuah pengantar ringkas). Jakarta Depdikbud

Devidoff, L. (1987).Introduction to psychology. New York, NY: MC. Graw Hill Book Company

Escarpit, R. (2008). Sosiologi sastra. Jakarta: Yayasan Obor Indonesia

Friedman, H.S., \& Schustack, M.W. (2008). Keperibadian teori klasik dan riset modern. (Terjemahan Firansiska Dian Ikarini, Maria Hany, \& Andreas Provita Prima). Upper Saddle River. NJ: Pearson Education, Inc. (Buku asli diterbitkan tahun 2006)

Gredler, M.E.B. (1986). Learning and instruction theory into practice. New York, NY. Macmillan publishing company

Hayati \& Muslih. (2012). Latihan apresiasi sastra: penunjang pengajaran bahasa dan sastra Indonesia di SMP dan SMA. Jakarta: Triana Media

Alwi, H., Lapoliwa., H., \& Darmowidjojo, S. (2003). Tata bahasa baku bahasa Indonesia edisi ketiga. Jakarta: Balai Pustaka

Ibrahim, L.F. (2011). The effect of intructioanal strategies and selfefficacy on students' achievement in reading comprehension. Tesis. Universitas Negeri Medan tidak diterbitkan

Ismail, T. (2013). Mendidik anak bangsa cinta membaca buku dan piawai mengarang. Makalah utama seminar nasional Jurusan pendidikan bahasa dan sastra Indonesia fakultas bahasa dan seni UNY disampaikan di auditorium UNY tanggal 19 November 2013.

Jabrohim, (2002). Fungsi didaktis sastra dalam pembangunan mental spritual dan integritas manusia indonesia. Yogyakarta: PIBSI XXVIII Universitas Ahmad Dahlan

Jamaluddin. (2003). Problematika pembelajaran bahasa \& sastra. Yogyakarta: Adicita Karya Nusa

Kompas. (2013). Skor PISA: Posisi Indonesia nyaris jadi juru kunci. sumber: Kompas cetak tanggal 5 Desember 2013.

Kompas. (2013). Mendikbud: Perkuat bahasa Indonesia di percaturan internasional!. di akses pada 2 Desember 2013 dari http://edukasi.kompas.com

Morton, J.B. (2010). Albama course of study English language arts, English language literacy for college and career readness. Alabama: Alabama Departement of education

Nilsen, A.P., \& Donelson, K.L. (2009). Literature for today's young adults. eight edition. Boston: Pearson education.

Nurgiyantoro, B. (2012). Penilaian pembelajaran bahasa. Yogyakarta: Fakultas ekonomika dan bisnis UGM

Partanto, P.A \& Barry, M.D.A. (2001). Kamus ilmiah populer. Surabaya: Arkola

Pertiwi, A.D. (2012). Pengaruh minat dan motivasi baca terhadap kemampuan meresepsi cerpen (studi pada siswa kelas 


\section{LingTera, 3 (1), May 2016 - 74}

Mimi Alpian, Maman Suryaman

IX SMP se- Kabupaten Banyumas). Skripsi tidak diterbitkan, Universitas Negeri Yogyakarta, Yogyakarta

Pulungan. I. (2008). Pengaruh metode pembelajaran dan motivasi belajar siswa terhadap hasil belajar kimia. Jurnal pendidikan, 47-52.

Puspendik. (2009). Laporan hasil dan Statistik nilai ujian nasional tahun pelajaran 2008/2009. Jakarta: Pusat Penilaian Pendidikan Badan Penelitian dan Pengembangan Departemen Pendidikan Nasional

Puspendik. (2010). Laporan hasil ujian nasional tahun pelajaran 2009/2010. Jakarta: BSNP-Pusat Penilaian Pendidikan Badan Penelitian dan Pengembangan Kementrian Pendidikan Nasional

Puspendik. (2011). Laporan hasil ujian nasional SMP/MTs tahun pelajaran 2010-2011. Jakarta: BSNP-Pusat Penilaian Pendidikan Badan Penelitian dan Pengembangan Kementrian Pendidikan Nasional

Puspendik. (2012). Laporan hasil ujian nasional SMP/MTs tahun pelajaran 2011-2012. Jakarta: BSNP-Pusat Penilaian Pendidikan Badan Penelitian dan Pengembangan Kementrian Pendidikan Nasional

Santrock, J. W. (2011). Psikologi pendidikan edisi ke 2 (terjemahan Tri Wibowo). New York, NY: McGraw-Hill Companies. (Buku asli diterbitkan tahun 2004)
Schunk, D. H. (2012). Lerning theories (6 $6^{\text {th }}$ ed.). Boston, MA: Pearson Education, Inc.

Sivapalan, S., Idrus, H., Bhattacharyya, E., Mordin, SM. (2008). Engineering student's perception of the influence of young adult literature on developing appreciation for reading. artikel The English teacher Vol. XXXVII: 27-39 Universiti Teknologi PETRONAS.

Sujarwanto \& Jabrohim, (Ed), (2002). Bahasa dan sastra Indonesia menuju peran transformasi social budaya abad XXI. Yogyakarta: PIBSI XXVIII Universitas Ahmad Dahlan

Suryaman, M. (2009). Panduan pendidikan dalam pembelajaran bahasa indonesia SMP/MTs. Jakarta: Pusat perbukuan departemen pendidikan nasional

Syah, M. (2010). Psikologi pendidikan suatu pendekatan baru. Bandung: Remaja Rosdakarya.

Uno, H.B. \& Koni, S. (2012). Asesmen pembelajaran. Jakarta: Bumi Aksara

Wade, C \& Tavris, C. (2007). Psokologi edisi kesembilan. (terjemahan oleh Padang mursalin \& Dinastuti). Upper Saddle River, NJ: Pearson Education, Inc. (Buku asli diterbitkan tahun 2006)

Woolfolk, A, (2007). Educational psychology tenth edition. Boston, MA: Pearson Education, Inc. 